\title{
Populasi
}

\section{Changes in Cost Incurred by Indonesian Teachers for Online Training during Covid-19 Pandemic}

\begin{abstract}
Al Azhar
Institute of Development and Empowerment of Educators and Education Personnel in Marine, Fisheries, Information, and Communication Technology, Ministry of Education and Culture of the Republic of Indonesia, Jalan Diklat No. 30, Patallassang, Gowa, South Sulawesi
\end{abstract}

Correspondence: Al Azhar (e-mail: adlyazhar@gmail.com)

\begin{abstract}
Due to Covid-19 transmission, the educational facilities in Indonesia were closed and teachers had to work from home (WFH). It caused face-to-face learning turn into online learning and online training. This study aimed to identify costs incurred by Indonesian teachers for online training during the Covid-19 pandemic. Data collection was carried out by distributing online questionnaires in Google forms to all teachers participating in the online training. Incoming responses were analyzed using SPSS version 26 . The results explained that by having selfisolation at home, teachers used their free time to attend online learning. However, they had to pay extra to buy good internet services to properly attend the training. Before the Covid-19 transmission period, the highest internet cost per month was IDR 0-100,000. While during the Covid-19 pandemic, the highest internet expense per month was IDR 100,000-200,000. It was described by the number of respondents who reached 306 respondents $(33.85 \%)$.
\end{abstract}

Keywords: Covid-19 pandemic; WFH; Indonesian teachers; online training; internet services

\section{Introduction}

The novel coronavirus diseases 2019 (Covid-19) is an infectious disease caused by a newly discovered type of coronavirus. This is a new virus and disease unknown before the outbreak in Wuhan, China, in December 2019 (Sohrabi et al. 2020; Yang et al. 2020). Before the end of December 2019 , the presence of a new virus had not been identified (Bruinen de Bruin et al. 2020). It can cause death, the first case was on 11 January in Wuhan (Al-Awadhi et al. 2020). Covid-19 had spread rapidly to various countries in the world (de Alwis et al.
2020) and every continent except Antarctica (Chakraborty and Maity 2020).

The Covid-19 pandemic has an impact on the lives of global society (Hagerty and Williams 2020; Mohler et al. 2020), economic sector (Ivanov 2020), and environment (Kerimray et al. 2020; Nakada and Urban 2020; Saadat, Rawtani, and Hussain 2020), including education (Nicola et al. 2020). Germany, Italia, United Kingdom, and over 100 other countries closed education facilities (Nicola et al. 2020).

Indonesia is one of the states affected by Covid-19 (Ali and Alharbi 2020; Djalante et al. 2020). However, there was no case 
of Covid-19 infection in Indonesia from December 2019 to February 2020. The first confirmed two cases in Indonesia were announced by President Joko Widodo on March 2, 2020 (Djalante et al. 2020). The number of infected cases is growing every day and the World Health Organization (WHO) set Covid-19 as a global pandemic that makes the Indonesian government establish a national disaster case.

The Minister for Empowerment of State Apparatuses and Bureaucratic Reform issued an official letter No. 19/2020 (Surat Edaran MenPANRB no 19/2020) regarding the adjustment of the work system of state civil apparatuses in preventing the spread of Covid-19 in Government on March 16, 2020. The letter contained face-to-face activities that invited many participants to be canceled (social distancing), employees of government agencies including education personnel (teachers) could work from home (WFH) and attend important meetings through video conferencing facilities. It was valid until March 31, then it was changed to Surat Edaran MenPANRB no. 34/2020. Its extension took into account Presidential Decree No. 11/2020 (on March 31, 2020) concerning Determination of Corona Virus Disease 2019 (Covid-19) Public Health Emergency and Presidential Decree No. $12 / 2020$ concerning Determination of Covid-19 as a National Disaster (on April 13, 2020). Surat Edaran MenPANRB no. $34 / 2020$ also regulated the sustainability of government and public services, adjustments to the work system under conditions of large-scale social restrictions (Pembatasan Sosial Berskala Besar/PSBB), and the use of the care concern application (aplikasi PeduliLindungi). This legal letter then changed with Surat Edaran MenPANRB no. $50 / 2020$ (on April 20, 2020) and 54/2020 (on May 12, 2020) which extended the isolation at a home period to May 29, 2020.

These policies have several impacts, including the closure of educational facilities.
The kindergarten, elementary school, junior high school, senior high school/vocational high school, and college were closed. It was intended to limit direct contact between students, teachers, and education staff to prevent the Covid-19 transmission. The school closure does not only negatively affect the performance of students (Sintema 2020), the students' psychology (Cao et al. 2020), and the academic staff's mental (Sahu 2020), but it also affects teachers. Teachers communicated with students online and attended a lot of training through online learning. The use of online learning media had increased significantly. Eventually, teachers add more expenses to buy internet data packages or pay for good internet services, during the Covid-19 pandemic. This study aims to identify changes in cost incurred by teachers before and during the Covid-19 pandemic.

\section{Material and Methods}

Data collection was carried out by distributing online questionnaires in Google forms to all teachers participating in the online training (learning process used WebEx event and Google classroom) on the preparation of online exam questions conducted on April 28 to May 14, 2020. Participants who gave responses as many as 904 teachers came from 32 provinces out of 34 in Indonesia.

Data analysis used SPSS version 26. Descriptive statistics were conducted to identify the demographic and other respondents' characteristics as well as the amount of internet package cost for online training during the Covid-19 pandemic. The participant distribution was mapped using ArcMap 10.3 software. To identify the changes in the cost for using internet services before and during the Covid-19 pandemic, it is processed into percentage data and displayed in graphical form. To describe the data characteristics collected was carried out a descriptive analysis. A univariate 
analysis was conducted to investigate the significant associations $(p<0.05)$ between the characteristics of respondents and internet cost during the Covid-19 pandemic (Cao et al., 2020). Spearman's correlation coefficient, $r$, was used to evaluate the level of closeness of the variables related to the cost of using the internet. A two-tailed $p<$ 0.05 was considered statistically significant. Statistically significant variables $(p<0.05)$ were selected for further analysis using ordinal logistic regression (multivariate analysis) (Cao et al., 2020; Zhou Zhu et al., 2020). It was to illustrate the relationship between ordinal-scale response variables and sample variables. A good fit model was determined by the goodness of fit test produced $p>0.05$. Odds ratio (OR) with a $95 \%$ confidence interval $(\mathrm{Cl})$ was used to illustrates the change in the tendency of each increase of a significant variable (Cao et al., 2020; Zhen Zhu et al., 2020).

\section{Results}

\section{Respondents' Distribution}

The number of respondents who gave their responses was varied by province. Of the total 904 respondents, the most four (above 10\%) came from West Sumatra at $17.81 \%$, South Sulawesi at $16.81 \%$, East Java at $14.38 \%$, and Central Java at $13.27 \%$. The fewest number of respondents $(0.11 \%)$ were Gorontalo, Central Kalimantan, North Maluku, West Nusa Tenggara, East Nusa Tenggara, and West Sulawesi. There were no respondents from the provinces of Bengkulu and Maluku. The percentage of respondents in all provinces is presented in Figure 1, and the distribution of respondent areas is shown in Figure 2.

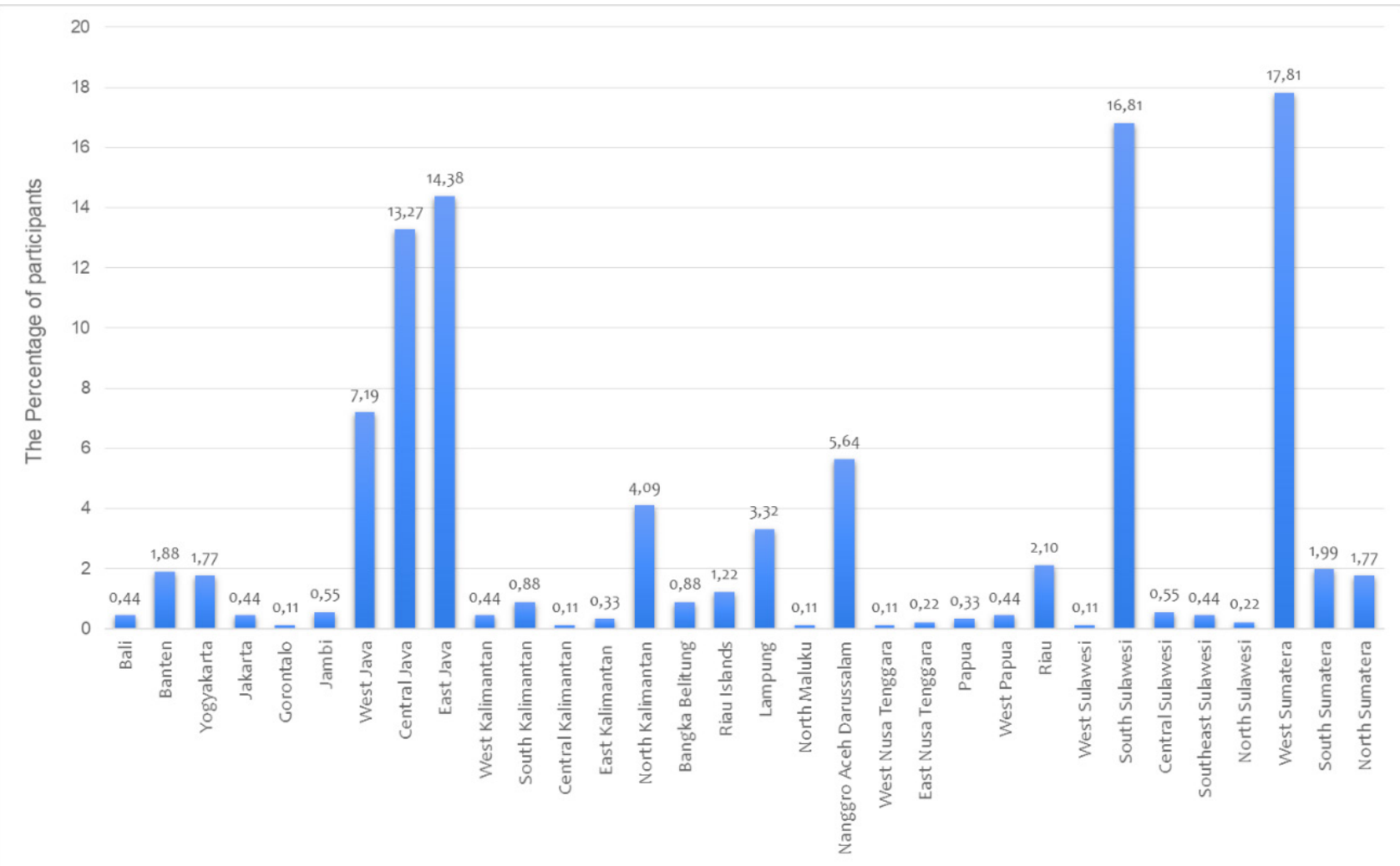

Figure 1. The percentage of respondents in all provinces, Indonesia 


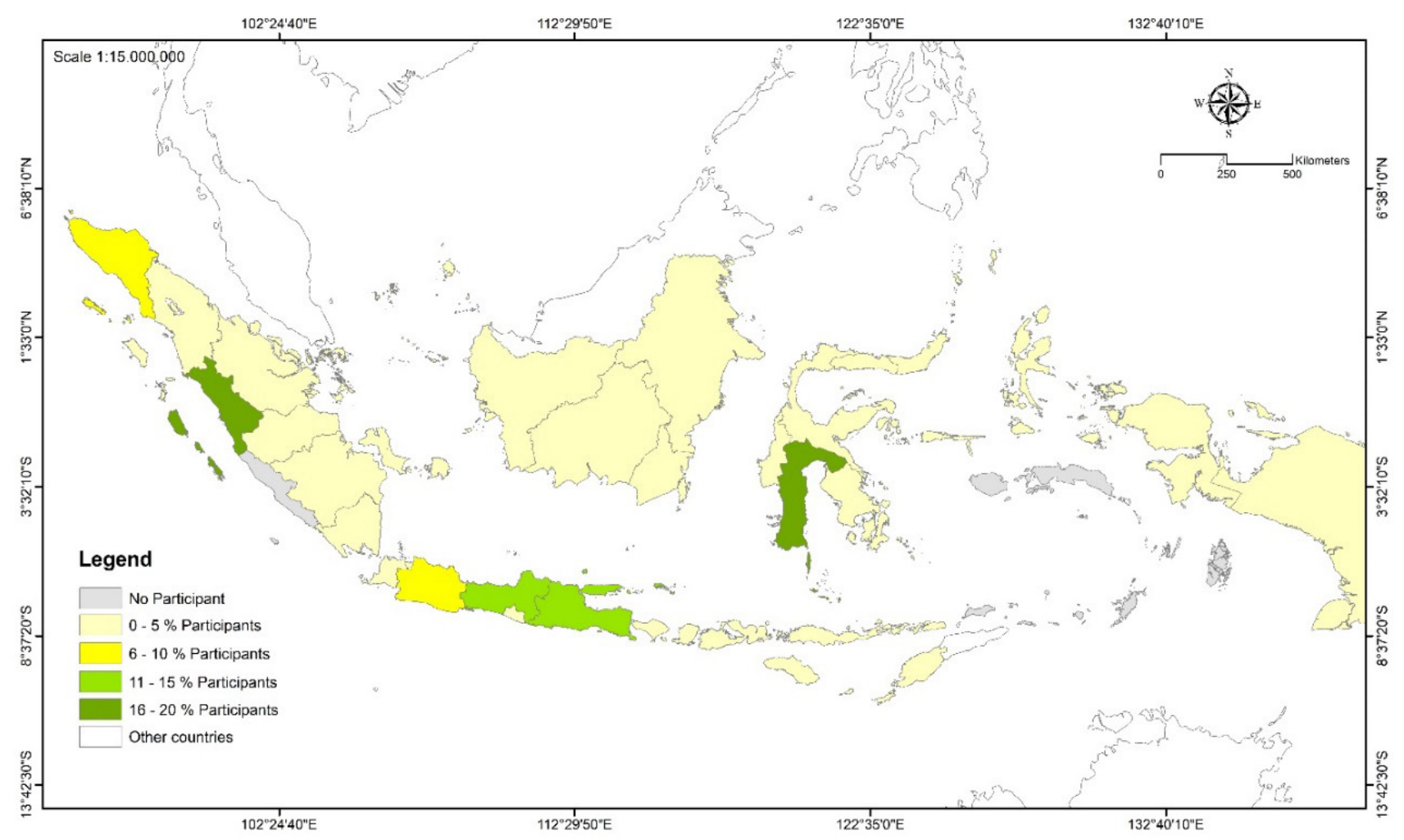

Figure 2. Distribution of respondents' areas

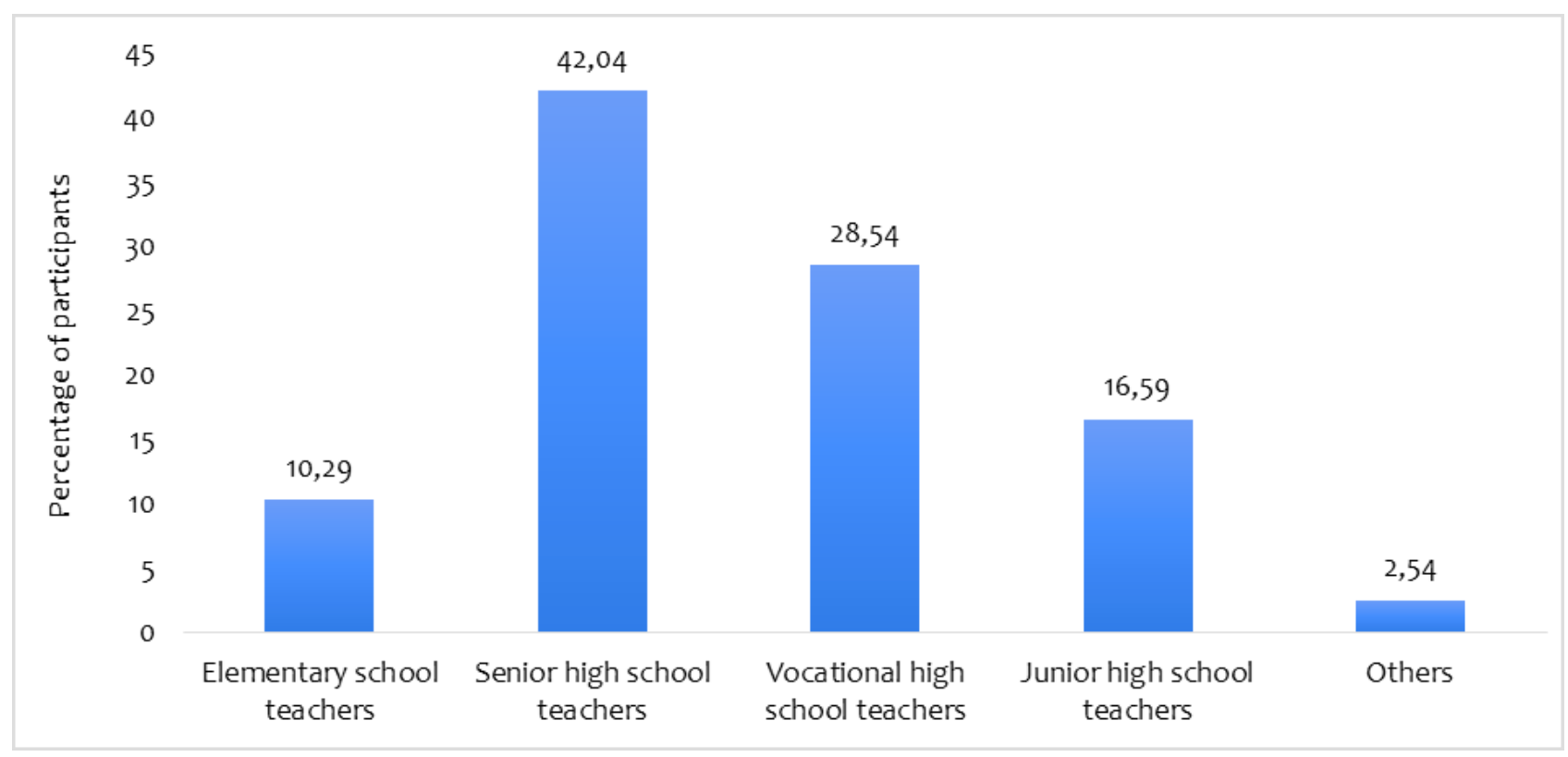

Figure 3. Characteristics of Respondents by Institution Level 
The Internet Service and Quota Usage

The internet services used by teachers before and during the Covid-19 pandemic included Indihome, XI home, Telkomsel, Indosat, Smartfren, Tri, and others. Among all services, Telkomsel is the most widely used, $53.43 \%$ (483 teachers). While the smallest one is $\mathrm{XI}$ home, $3.32 \%$ (30 respondents). The Internet services used in Indonesia based on teacher responses before and during the Covid-19 pandemic can be seen in Table 1.

The amount of internet quota spent on online training during the Covid-19 pandemic
(68 lesson hours) varied among respondents. There were 156 respondents (17.26\%) who used the most internet quota at 15-20 GB, 153 respondents $(16.92 \%)$ consumed 6-10 $\mathrm{GB}$, and 145 respondents (16.04\%) deplete 11-15 GB. Moreover, the use of internet data above 50 GB was answered by 78 respondents (8.63\%). The smallest internet quota usage is at $41-45 \mathrm{~GB}$, which is 23 respondents $(2.54 \%)$. The usage quota of the internet used by respondents during the Covid-19 pandemic is shown in Figure 4.

Table 1. The internet services used in Indonesia based on teacher responses

\begin{tabular}{clcr}
\hline No. & Internet services & Number of respondents & Percentage (\%) \\
\hline 1. & Indihome & 147 & 16.26 \\
2. & Xl home & 30 & 3.32 \\
3. & Telkomsel & 483 & 53.43 \\
4. & Indosat & 93 & 10.29 \\
5. & Smartfren & 39 & 4.31 \\
6. & Tri & 59 & 6.53 \\
7. & Others & 53 & 5.86 \\
\hline Total & 904 & 100.00 \\
\hline
\end{tabular}

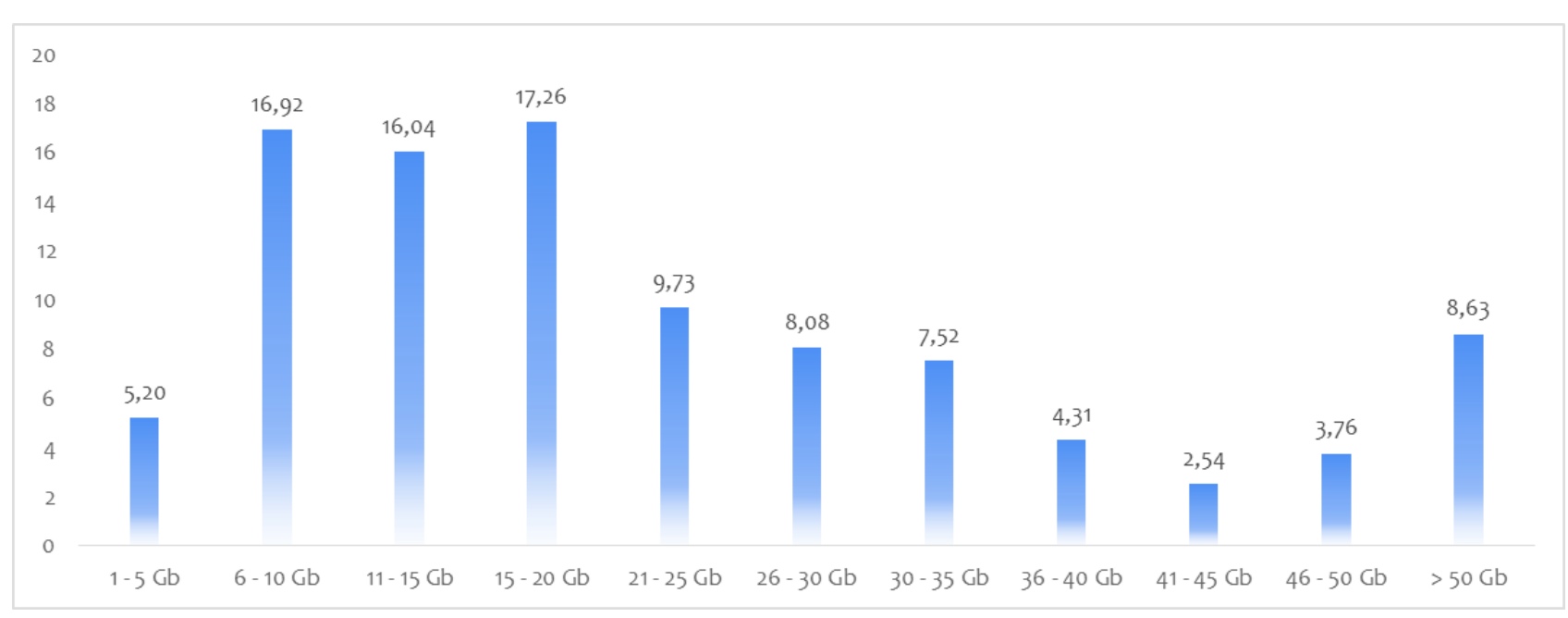

Figure 4. Internet quota used by respondents during the Covid-19 pandemic 
Cost for Internet Services Incurred before and during the Covid-19 Pandemic

The cost incurred by the teachers differed before and during Covid-19 transmission. The reason was that many teachers took part in online learning during the pandemic, so there was additional cost to purchase more with better internet packages. Before the Covid-19 transmission period, the four highest internet expenses per month were IDR $0-100,000$; IDR 100,000-200,000; IDR 200,000-300,000; IDR 300,000-400,000, respectively. There were 323 respondents $(35.73 \%)$ stated that the cost of internet packages issued was at most under IDR 100,000 per month; 313 teachers $(34.62 \%)$ said that the internet costs were around IDR 100,000 - 200,000 per month; 144 respondents $(15,93 \%)$ spend IDR 200,000-300,000 per month; and 76 responses consumed IDR 300,000-400,000 per month. During the Covid-19 pandemic, the four highest internet expenses per month were IDR 100,000-200,000; IDR 200,000-300,000; IDR 300,000-400,000; IDR 0-100,000; respectively. There were 306 respondents $(33.85 \%)$ who stated that the cost of internet packages issued was IDR 100,000 - 200,000 per month; 278 teachers $(30.75 \%)$ said that the internet costs were around IDR 200,000 - 300,000 per month; 143 respondents $(15,82 \%)$ spend IDR 300,000-400,000 per month; and 82 respondents consumed under IDR 100,000 per month. There was a respondent who spent his money to buy internet service above IDR 1 million. During the pandemic, the range of expenses from IDR 700,000 to 800,000 increased to 3 respondents and 2 respondents $(0.22 \%)$ purchased internet quota between IDR 800,000 and IDR 900,000 . The costs of internet services that incurred before and during the Covid-19 pandemic were described in Figure 5.

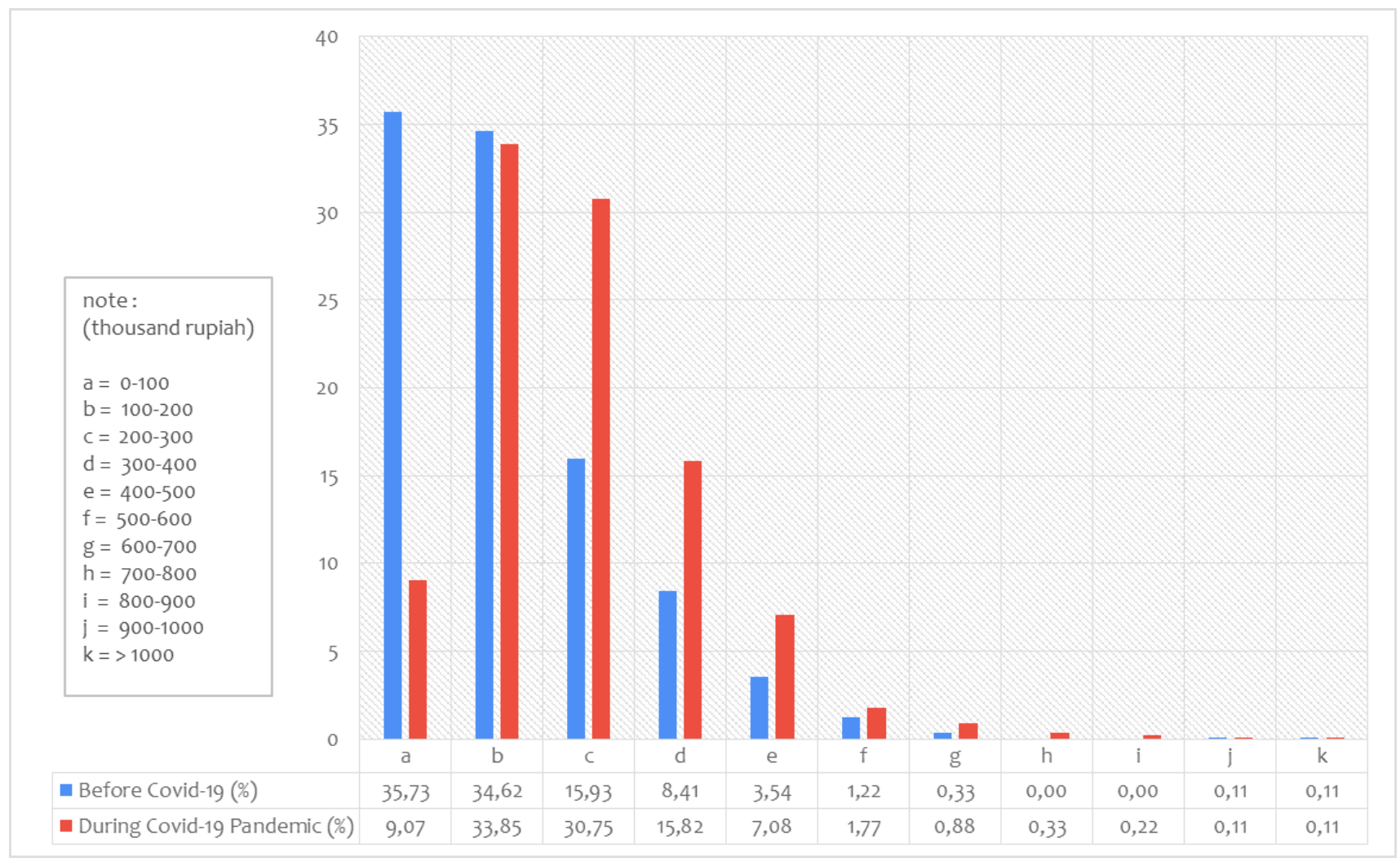

Figure 5. Costs of internet services incurred before and during the Covid-19 pandemic 
Based on the results of data analysis, the internet service used the most by the respondents during the Covid-19 pandemic were Telkomsel, then Indihome, and Indosat. For instance, in the use of IDR 100,000200,000 , the number of respondents using Telkomsel reached $18.25 \%$ (165 persons), while those who used Indihome and Indosat were $4.98 \%$ (45 persons) and $3.65 \%$ (33 persons), respectively. In the use of IDR $200,000-300,000$, the number of teachers using Telkomsel reached $17.26 \% \quad(156$ persons), while those who used Indihome and Indosat were $4.98 \%$ (45 persons) and $2.65 \%$ (24 persons), respectively. The third-largest internet quota usage was IDR 300,000400,000 , the number of respondents using Telkomsel reached $8.19 \%$ (74 persons), while those who used Indihome and XI home were $4.87 \%$ (44 persons) and $0.88 \%$ (8 persons), respectively. For more details, the use of internet services during the Covid-19 pandemic is presented in Figure 6.

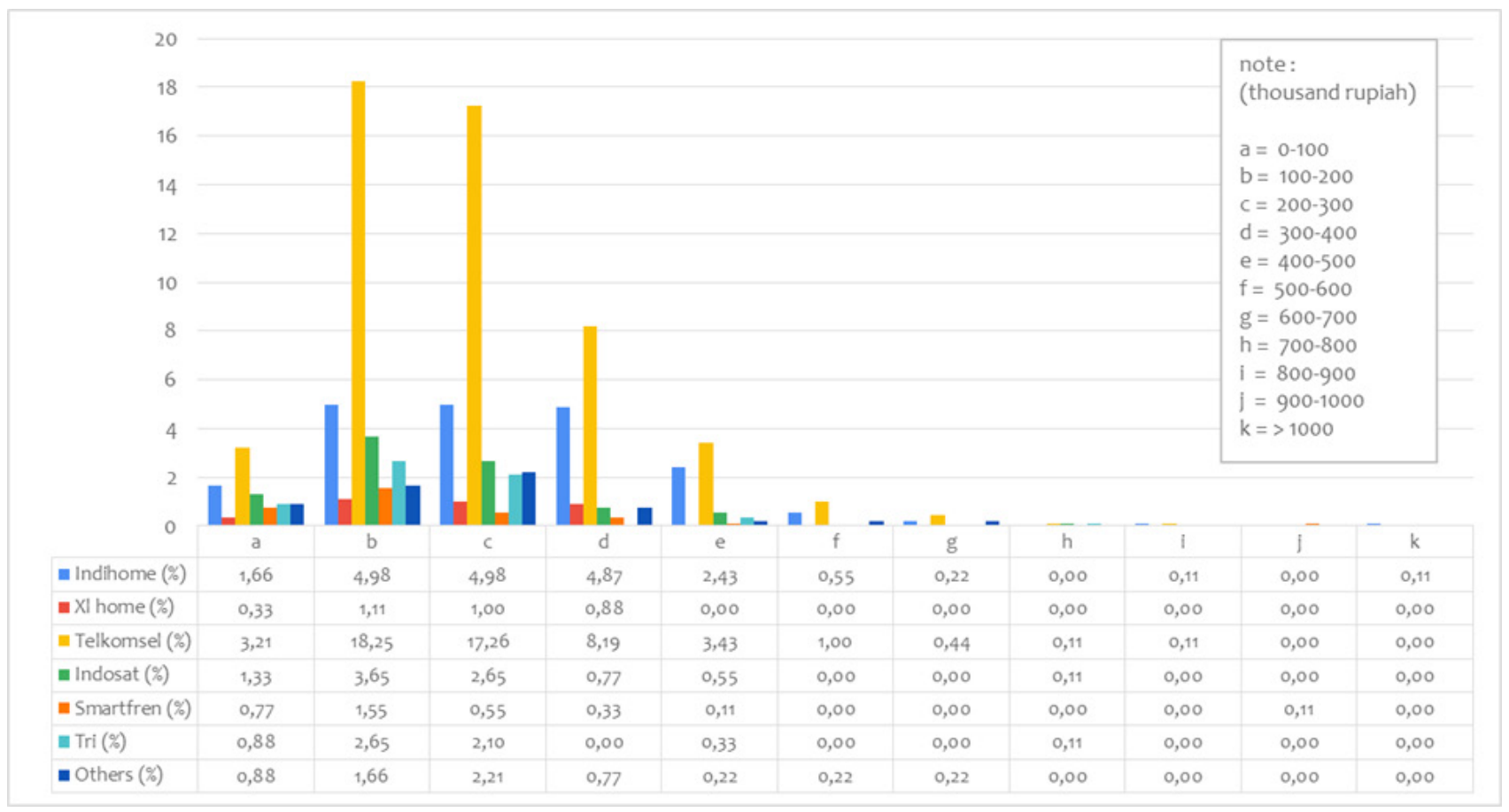

Figure 6. The use of internet services during the covid-19 pandemic 
Univariate Analysis and Correlation of the Variables Related to the Cost

The analysis results of 6 sample characteristic variables associated with internet cost during the covid-19 pandemic were obtained education level ( $p$-value 0.001 ), internet services ( $p$-value 0.000$)$, and internet quota ( $p$-value 0.000$)$ which had a significant effect, $p$-value $<0.05$ (table 2 ).

Table 2. Univariate analysis of the internet cost during Covid-19 pandemic

\begin{tabular}{|c|c|c|c|c|}
\hline No. & Variables & Total & Mean Rank & $\mathbf{P}$ \\
\hline \multirow[t]{3}{*}{1.} & Gender & & & \\
\hline & Male & $286(31.64 \%)$ & 449.55 & $0.810^{a}$ \\
\hline & Female & $618(68.36 \%)$ & 453.87 & \\
\hline \multirow[t]{4}{*}{2.} & Education & & & \\
\hline & Diploma & $4(00.44 \%)$ & 0.44 & $0.001^{b *}$ \\
\hline & Bachelor & $666(73.67 \%)$ & 436.67 & \\
\hline & Master & $234(25.88 \%)$ & 500.91 & \\
\hline \multirow[t]{5}{*}{3.} & Job Position & & & \\
\hline & Elementary school & $93(10.29 \%)$ & 462.37 & $0.329^{b}$ \\
\hline & Junior high school & $150(16.59 \%)$ & 424.46 & \\
\hline & Senior high school & $638(70.58 \%)$ & 455.47 & \\
\hline & Vocational high school & $23(2.54 \%)$ & 513.09 & \\
\hline \multirow[t]{8}{*}{4.} & Internet services & & & \\
\hline & Indihome & $147(16.26 \%)$ & 537.73 & $0.000^{b *}$ \\
\hline & XI home & $30(3.32 \%)$ & 441.15 & \\
\hline & Telkomsel & $483(53.43 \%)$ & 459.45 & \\
\hline & Indosat & $93(10.29 \%)$ & 387.10 & \\
\hline & Smartfren & $39(4.31 \%)$ & 358.08 & \\
\hline & Tri & $59(6.53 \%)$ & 365.89 & \\
\hline & Others & $53(5.86 \%)$ & 439.86 & \\
\hline \multirow[t]{12}{*}{5} & Internet Quota & & & \\
\hline & $1-5 \mathrm{~Gb}$ & $47(5.20 \%)$ & 275.88 & $0.000^{b *}$ \\
\hline & $6-10 \mathrm{~Gb}$ & $153(16.92 \%)$ & 335.67 & \\
\hline & $11-15 G b$ & $145(16.04 \%)$ & 374.29 & \\
\hline & $16-20 \mathrm{~Gb}$ & $156(17.26 \%)$ & 420.40 & \\
\hline & $21-25 \mathrm{~Gb}$ & $88(9.73 \%)$ & 494.49 & \\
\hline & $26-30 \mathrm{~Gb}$ & $73(8.08 \%)$ & 532.68 & \\
\hline & $31-35 G b$ & $68(7.52 \%)$ & 613.18 & \\
\hline & $36-40 \mathrm{~Gb}$ & $39(4.31 \%)$ & 566.31 & \\
\hline & $41-45 \mathrm{~Gb}$ & $23(2.54 \%)$ & 608.91 & \\
\hline & $46-50 \mathrm{~Gb}$ & $34(3.76 \%)$ & 578.37 & \\
\hline & $>50 \mathrm{~Gb}$ & $78(8.63 \%)$ & 577.29 & \\
\hline
\end{tabular}

aMann-Whitney test; ${ }^{\text {} K r u s k a l-W a l l s ~ t e s t ; ~ * a ~ s i g n i f i c a n t ~ v a r i a b l e ~}$ 
Each variable has a different level of relationship with internet usage. Sequentially, the level of education, internet services, and internet quota has a correlation of $r=0.118, r$ $=0.178$, and $r=0.403$. This shows that each internet provider provides internet packages with varying prices, as well as the greater the cost incurred to buy an internet package, the greater the quota that can be obtained.

\section{Ordinal Regression Analysis}

Table 3 shows the results of ordinal regression analysis between education, internet services, and internet quota with internet cost. These variables were included in the multivariate analysis because they had a significant influence on intenet cost $(p<0.05)$. The parallel lines test obtained a chi-square value of 1129.17 and the null hypothesis stated that the location parameters (slope coefficients) were the same across response categories. Based on the simultaneous test results, chisquare $227.91, p$-value $(0.000)<0.05$, and goodness of fit $(p 1.000>0.05)$, it shows that the regression model used at a $95 \%$ confidence level was suitable.

Table 3. Ordinal logistic regression analysis of factors influencing the internet cost

\begin{tabular}{|c|c|c|c|c|c|c|}
\hline No. & Factors & Number & SE & OR & $\mathbf{P}$ & OR $(95 \% \mathrm{Cl})$ \\
\hline \multirow[t]{3}{*}{1.} & Education & & & & & \\
\hline & Diploma & $4(00.44 \%)$ & 1.036 & 19.67 & 0.004 & $\begin{array}{l}(-5.01 ; \\
-0.95)\end{array}$ \\
\hline & Bachelor & $666(73.67 \%)$ & 0.140 & 1.49 & 0.005 & $\begin{array}{l}(-0.67 \\
-0.12)\end{array}$ \\
\hline \multirow[t]{2}{*}{2.} & Internet services & & & & & \\
\hline & Indihome & $147(16.26 \%)$ & 0.296 & 2.95 & 0.000 & $\begin{array}{l}(0.502 ; \\
1.661)\end{array}$ \\
\hline \multirow[t]{6}{*}{3.} & Internet quota & & & & & \\
\hline & $1-5 \mathrm{~Gb}$ & $47(5.20 \%)$ & 0.354 & 15.17 & 0.000 & $\begin{array}{l}(-3.41 \\
-2.03)\end{array}$ \\
\hline & $6-10 \mathrm{~Gb}$ & $153(16.92 \%)$ & 0.263 & 6.65 & 0.000 & $\begin{array}{l}(-2.41 \\
-1.38)\end{array}$ \\
\hline & $11-15 G b$ & $145(16.04 \%)$ & 0.264 & 4.55 & 0.000 & $\begin{array}{l}(-2.03 \\
-0.99)\end{array}$ \\
\hline & $16-20 \mathrm{~Gb}$ & $156(17.26 \%)$ & 0.258 & 3.31 & 0.000 & $\begin{array}{l}(-1.70 \\
-0.69)\end{array}$ \\
\hline & $21-25 \mathrm{~Gb}$ & $88(9.73 \%)$ & 0.285 & 1.86 & 0.030 & $\begin{array}{l}(-1.17 \\
-0.59)\end{array}$ \\
\hline
\end{tabular}

*SE = standard error; OR = odds ratio; $\mathrm{Cl}=$ confidence interval

The results show that respondents with diploma degrees $(\mathrm{OR}=19.67,95 \% \mathrm{Cl}=-5.01$; -0.95) used internet packages which were 19.67 times cheaper than those with higher education levels. Teachers using Indihome
$(\mathrm{OR}=2.95,95 \% \mathrm{Cl}=0.502 ; 1,661)$ tended to spend about 2.96 times less in one online training than others. Likewise, the smaller the internet quota used, the smaller the cost incurred to complete online learning. 


\section{Discussion}

In Indonesia, the Covid-19 pandemic and additional cost for teachers to purchase good internet services are cause and effect events. Covid-19 is a major causal factor that impacts isolated at home (WFH) for most Indonesians including teachers, which is legally supported through the Surat Edaran MenPANRB No. 19 , No. 34 , No. 50 , and No. 54 in 2020. WFH requires teachers to work at home, causing the need for online learning increase dramatically. In addition to communicating, teaching, and learning with students online, teachers also take part in online training. Finally, the intensity of internet access increases, causing additional cost for purchasing internet services better. The Covid-19 pandemic causal relationship with the cost of purchasing internet services better can be described simply in Figure 7 .

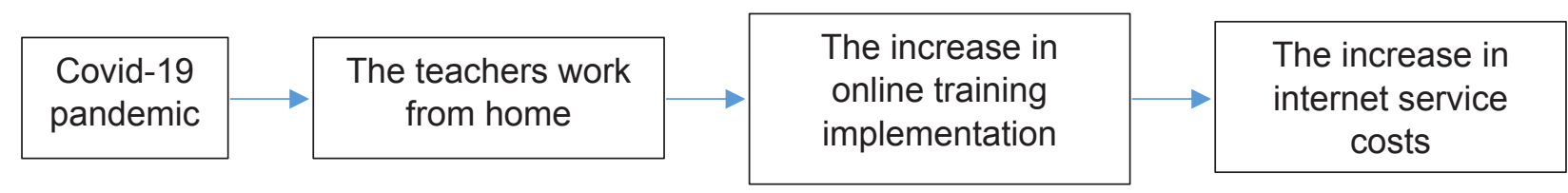

Figure 7. The Covid-19 pandemic causal relationship with the cost of purchasing internet services better

The number of Covid-19 infected cases in Indonesia is raising. The first distribution was in Jakarta, and it then formed new clusters in the surrounding areas, such as West Java and Banten. This is because the epicenter distance is a very strong influential parameter in Covid-19 transmission (Liu 2020). Based on data obtained from http:// covid19.go.id dated May 20, 2020, stated In Indonesia, confirmed cases of Covid-19 were 191,189 patients, consisting of 133,372 persons in care, 4,575 persons recovered, and 1,242 persons died. Covid-19 can infect everyone, but older people are more vulnerable and have a higher fatality rate than the younger ones (Niu et al. 2020).

Covid-19 has an impact on the economy and education sector, especially for teachers. Teaching and learning processes that were used to be done in formal schools, as well as competency improvement training programs followed by teachers through face-to-face learning, turn into online-based learning. The impact felt by teachers was the increasing cost of using the internet for online learning. Before the pandemic, teachers only spent money on internet quota up to IDR 100,000
(35.73\%), IDR 200,000 (34.62\%), and IDR 300,000 (15.93\%). Meanwhile, during the pandemic, the internet costs incurred by teachers were up to IDR 200,000 (33.85\%), IDR 300,000 (30.75\%), and IDR 400,000 $(15.82 \%)$. Education level, internet services, and internet quota are variables that have a real effect and have a correlation with the number of costs incurred by teachers. These three variables have a $p$-value $<0.05$ with the level of closeness of each relationship is education $(r=0.118)$, internet services $(r=0.178)$, and internet quota $(r=0.403)$. Respondents who had a diploma level of education tend to spend cheaper internet costs $(\mathrm{OR}=19.67,95 \% \mathrm{Cl}=-5.01 ;-0.95)$ than bachelors let alone masters. Teachers who used Indihome $(\mathrm{OR}=2.95,95 \% \mathrm{Cl}=$ $0.502 ; 1.661)$ were easier and less costly than buying quotas or data packages continuously when participating in the training. Likewise, teachers who used small quotas would reduce the cost.

Online learning has advantages and disadvantages. The advantage is that teachers have more effective time and place, directly joined the learning process from 
home, were more independent by increasing knowledge through references on the internet, and were trained to better master the ever-evolving information technology. The positive things gained from online training have also been explained from several previous studies. The teachers' competency improvement online training and blended mode well developed to replace face-to-face learning (Jonker, März, and Voogt 2018; Yeh, Huang, and Yeh 2011). The benefits of online training are convenient for teachers to follow, even at home (Chen, Chen, and Tsai 2009; Ching and Hursh 2014; Zhang and Liu 2019) and more flexible (Powell and Bodur 2019); give good knowledge, confidence, and great motivation to the teacher (Hoffman et al. 2019; Liu 2017); can communicate with experts (Macià and García 2016; Prenger, Poortman, and Handelzalts 2017) and more interactive with each other (Blaine 2019; Tseng and Kuo 2014); well combined constructive knowledge and active knowledge (Atapattu et al. 2019); provide insight development and more intense use of information technology or internet (Chow, Tse, and Armatas 2018; Karaseva 2016).

While the lacks of online training are more theoretical learning and minimal practice, for teachers living in locations with still lacking communication infrastructure, of course, it will be difficult to access the internet. Not all teachers have a good ability to operate computers or laptops, and too much distraction that can disrupt the concentration of the teachers while training. The most important thing, online learning has an impact on the increase in expenses or costs incurred by teachers to access the internet better.

Several studies were describing the lack of online training. For teachers who have limited internet access time when online training and lack of experience operating computers or online applications become a significant obstacle to contribute well in online training (Tsiotakis and Jimoyiannis 2016). It is difficult to control which participants are serious or not during taking lessons (Zhang and Liu 2019). Moreover, during online training, teachers must be non-stress due to household problems, social intercourses, and personal relationships (Taylor et al. 2019).

\section{Conclusion}

Covid-19 pandemic had influenced the habits of Indonesian people, including the economy and education sectors. Since mid-March 2020, education facilities had been closed, teachers and all education staff throughout Indonesia were forced to work from home (WFH) to prevent rapid Covid-19 transmission. WFH has an impact on increasing the use of online applications for online-based learning. Such conditions make teachers have to spend more money to buy internet data packages that are better than before the Covid-19 pandemic.

Before the Covid-19 transmission period, the highest internet costs per month was IDR $0-100,000$. It was evidenced by the number of respondents that reached 323 persons (35.73\%). Meanwhile, during the Covid-19 pandemic, the highest internet expenses per month were IDR $100,000-200,000$. It was identified by the number of respondents that reached 306 persons (33.85\%). Also, the internet costs ranging from IDR 200,000 300,000 per month was responded by 278 teachers $(30.75 \%)$.

\section{References}

Al-Awadhi, Abdullah M., Khaled Alsaifi, Ahmad Al-Awadhi, and Salah Alhammadi. 2020. "Death and Contagious Infectious Diseases: Impact of the COVID-19 Virus on Stock Market Returns." Journal of Behavioral and Experimental Finance.

Ali, Imran, and Omar M. L. Alharbi. 2020. "COVID-19: Disease, Management, 
Treatment, and Social Impact." Science of the Total Environment 728:138861.

de Alwis, Ruklanthi, Shiwei Chen, Esther S.

Gan, and Eng Eong Ooi. 2020. "Impact of Immune Enhancement on Covid-19 Polyclonal Hyperimmune Globulin Therapy and Vaccine Development." EBioMedicine.

Atapattu, Thushari, Menasha Thilakaratne, Rebecca Vivian, and Katrina Falkner. 2019. "Detecting Cognitive Engagement Using Word Embeddings within an Online Teacher Professional Development Community." Computers and Education 140(January):103594.

Blaine, Andrew M. 2019. "Interaction and Presence in the Virtual Classroom: An Analysis of the Perceptions of Students and Teachers in Online and Blended Advanced Placement Courses." Computers and Education 132(December 2018):31-43.

Bruinen de Bruin, Yuri, Anne Sophie Lequarre, Josephine McCourt, Peter Clevestig, Filippo Pigazzani, Maryam Zare Jeddi, Claudio Colosio, and Margarida Goulart. 2020. "Initial Impacts of Global Risk Mitigation Measures Taken during the Combatting of the COVID-19 Pandemic." Safety Science.

Cao, Wenjun, Ziwei Fang, Guoqiang Hou, Mei Han, Xinrong Xu, Jiaxin Dong, and Jianzhong Zheng. 2020. "The Psychological Impact of the COVID-19 Epidemic on College Students in China." Psychiatry Research.

Chakraborty, Indranil, and Prasenjit Maity. 2020. "COVID-19 Outbreak: Migration, Effects on Society, Global Environment and Prevention." Science of the Total Environment.

Chen, Yihsuan, Nian Shing Chen, and Chin Chung Tsai. 2009. "The Use of Online Synchronous Discussion for WebBased Professional Development for Teachers." Computers and Education 53(4):1155-66.
Ching, Cynthia Carter, and Anthony W. Hursh. 2014. "Peer Modeling and Innovation Adoption among Teachers in Online Professional Development." Computers and Education 73:72-82.

Chow, Joseph, Ada Tse, and Christine Armatas. 2018. "Comparing Trained and Untrained Teachers on Their Use of LMS Tools Using the Rasch Analysis." Computers and Education 123:124-37. Djalante, Riyanti, Jonatan Lassa, Davin Setiamarga, Aruminingsih Sudjatma, Mochamad Indrawan, Budi Haryanto, Choirul Mahfud, Muhammad Sabaruddin Sinapoy, Susanti Djalante, Irina Rafliana, Lalu Adi Gunawan, Gusti Ayu Ketut Surtiari, and Henny Warsilah. 2020. "Review and Analysis of Current Responses to COVID-19 in Indonesia: Period of January to March 2020." Progress in Disaster Science.

Hagerty, Sarah L., and Leanne M. Williams. 2020. "The Impact of Covid-19 on Mental Health: The Interactive Roles of Brain Biotypes and Human Connection." Brain, Behavior, \& Immunity Health 5 (April): 100078.

Hoffman, Jessica A., Ellyn M. Schmidt, Carmen Castaneda-Sceppa, and Charles H. Hillman. 2019. "The Theoretical Foundation, Fidelity, Feasibility, and Acceptability of a Teacher Training to Promote Physical Activity among Preschoolers in Child Care:APilot Study." Preventive Medicine Reports 13 (December 2018): 214-17.

Ivanov, Dmitry. 2020. "Predicting the Impacts of Epidemic Outbreaks on Global Supply Chains: A Simulation-Based Analysis on the Coronavirus Outbreak (COVID-19/ SARS-CoV-2) Case." Transportation Research Part E: Logistics and Transportation Review.

Jonker, Herma, Virginie März, and Joke Voogt. 2018. "Teacher Educators' Professional Identity under Construction: The Transition from Teaching Face-to- 
Face to a Blended Curriculum." Teaching and Teacher Education 71:120-33.

Karaseva, Agnese. 2016. "Relationship of Internet Self-Efficacy and Online Search Performance of Secondary School Teachers." Procedia - Social and Behavioral Sciences 231(May): 278-85. Kerimray, Aiymgul, Nassiba Baimatova, Olga

P. Ibragimova, Bauyrzhan Bukenov, Bulat Kenessov, Pavel Plotitsyn, and Ferhat Karaca. 2020. "Assessing Air Quality Changes in Large Cities during COVID-19 Lockdowns: The Impacts of Traffic-Free Urban Conditions in Almaty, Kazakhstan." Science of the Total Environment 730:139179.

Liu, Lu. 2020. "Emerging Study on the Transmission of the Novel Coronavirus ( COVID-19) from Urban Perspective : Evidence from China." Cities 103 (March): 102759.

Liu, Shih Hsiung. 2017. "Relationship between the Factors Influencing Online Help-Seeking and Self-Regulated Learning among Taiwanese Preservice Teachers." Computers in Human Behavior 72: 38-45.

Macià, Maria, and Iolanda García. 2016. "Informal Online Communities and Networks as a Source of Teacher Professional Development: A Review." Teaching and Teacher Education 55: 291-307.

Mohler, George, Andrea L. Bertozzi, Jeremy Carter, Martin B. Short, Daniel Sledge, George E. Tita, Craig D. Uchida, and P. Jeffrey Brantingham. 2020. "Impact of Social Distancing during COVID-19 Pandemic on Crime in Indianapolis." 68 (April).

Nakada, Liane Yuri Kondo, and Rodrigo Custodio Urban. 2020. "COVID-19 Pandemic: Impacts on the Air Quality during the Partial Lockdown in São Paulo State, Brazil." Science of The Total Environment.
Nicola, Maria, Zaid Alsafi, Catrin Sohrabi, Ahmed Kerwan, Ahmed Al-Jabir, Christos losifidis, Maliha Agha, and Riaz Agha. 2020. "The Socio-Economic Implications of the Coronavirus and COVID-19 Pandemic: A Review." International Journal of Surgery 78 (March): 185-93.

Niu, Shengmei, Sijia Tian, Jing Lou, Xuqin Kang, Luxi Zhang, Huixin Lian, and Jinjun Zhang. 2020. "Clinical Characteristics of Older Patients Infected with COVID-19: A Descriptive Study." Archives of Gerontology and Geriatrics 89 (March): 104058.

Powell, Cathy G., and Yasar Bodur. 2019. "Teachers' Perceptions of an Online Professional Development Experience: Implications for a Design and Implementation Framework." Teaching and Teacher Education 77: 19-30.

Prenger, Rilana, Cindy L. Poortman, and Adam Handelzalts. 2017. "Factors Influencing Teachers' Professional Development in Networked Professional Learning Communities." Teaching and Teacher Education 68: 77-90.

Saadat, Saeida, Deepak Rawtani, and Chaudhery Mustansar Hussain. 2020. "Environmental Perspective of COVID-19." Science of the Total Environment.

Sahu, Pradeep. 2020. "Closure of Universities Due to Coronavirus Disease 2019 (COVID-19): Impact on Education and Mental Health of Students and Academic Staff." Cureus 2019 (April).

Sintema, Edgar John. 2020. "Effect of COVID-19 on the Performance of Grade 12 Students: Implications for STEM Education." Eurasia Journal of Mathematics, Science and Technology Education 16 (7).

Sohrabi, Catrin, Zaid Alsafi, Niamh O'Neill, Mehdi Khan, Ahmed Kerwan, Ahmed Al-Jabir, Christos losifidis, and Riaz 
Agha. 2020. "World Health Organization Declares Global Emergency: A Review of the 2019 Novel Coronavirus (COVID-19)." International Journal of Surgery 76: 71-76.

Taylor, Michelle, Leigh McLean, Crystal I. Bryce, Tashia Abry, and Kristen L. Granger. 2019. "The Influence of Multiple Life Stressors during Teacher Training on Burnout and Career Optimism in the First Year of Teaching." Teaching and Teacher Education 86 (2019): 102910.

Tseng, Fan Chuan, and Feng Yang Kuo. 2014. "A Study of Social Participation and Knowledge Sharing in the Teachers' Online Professional Community of Practice." Computers and Education 72: 37-47.

Tsiotakis, Panagiotis, and Athanassios Jimoyiannis. 2016. "Critical Factors towards Analysing Teachers' Presence in on-Line Learning Communities." Internet and Higher Education 28: 4558.

Yang, Jing, Ya Zheng, Xi Gou, Ke Pu, Zhaofeng Chen, Qinghong Guo, Rui $\mathrm{Ji}$, Haojia Wang, Yuping Wang, and Yongning Zhou. 2020. "Prevalence of Comorbidities and Its Effects in Coronavirus Disease 2019 Patients: A Systematic Review and Meta-Analysis." International Journal of Infectious Diseases 94: 91-95.
Yeh, Yu Chu, Ling Yi Huang, and Yi Ling Yeh. 2011. "Knowledge Management in Blended Learning: Effects on Professional Development in Creativity Instruction." Computers and Education 56 (1): 146-56.

Zhang, Si, and Qingtang Liu. 2019. "Investigating the Relationships among Teachers' Motivational Beliefs, Motivational Regulation, and Their Learning Engagement in Online Professional Learning Communities." Computers and Education 134 (February): 145-55.

Zhu, Zhen, Liu, Q., Jiang, X., Manandhar, U., Luo, Z., Zheng, X., Li, Y., Xie, J., \& Zhang, B. (2020). The psychological status of people affected by the COVID-19 outbreak in China. Journal of Psychiatric Research, 129 (April), 1-7. https://doi. org/10.1016/j.jpsychires.2020.05.026.

Zhu, Zhou, Xu, S., Wang, H., Liu, Z., Wu, J., Li, G., Miao, J., Zhang, C., Yang, Y., Sun, W., Zhu, S., Fan, Y., Hu, J., Liu, J., \& Wang, W. 2020. COVID-19 in Wuhan: Sociodemographic Characteristics and Hospital Support Measures Associated with the Immediate Psychological Impact on Healthcare Workers. SSRN Electronic Journal, 000, 100443. https:// doi.org/10.2139/ssrn.3578747. 